\title{
THE NORTHERN WORLD OF THE ANGLO-SAXON MAPPA MUNDI
}

\section{INTRODUCTION: THE ANGLO-SAXON MAPPA MUNDI IN CONTEXT}

The only surviving mappa mundi from Anglo-Saxon England (fig. 1) is found on folio 56v of London, British Library, Cotton Tiberius B.v (s.xi $\left.{ }^{2 / 4}\right){ }^{1}$ This detailed map of the oecumene, the inhabited world, presents a distinctive cartography that reflects a particularly Anglo-Saxon geographic imagination. An exploration of how the AngloSaxon mappa mundi, sometimes called the Cotton Map or the Cottoniana, represents space reveals its northern perspective, affording insights into the information sources used in its composition and the worldview of its creators. The map contains material derived from Biblical and especially Roman geography, and its detailed depiction of Northwestern Europe suggests connections to the Viking world. The map echoes the interests of the Old English Orosius, particularly the geographical section, which may be one of the sources of its exemplar. The Anglo-Saxon mappa mundi is arguably a copy of an earlier, larger Anglo-Saxon map - itself derived from the Carolingian transmission of Roman cartography - that adapted and reconfigured inherited material to represent the perspective of an assertive tenth-century England. The mappa mundi (and its putative exemplum) presents the integration of inherited learning and regional knowledge to create a distinctive and confident Insular view of the world that suggests the movement of power and influence to later Anglo-Saxon England.

The manuscript containing the mappa mundi was produced around 1025-50, during the reign of Canute or his successors, possibly in Canterbury. ${ }^{2}$ Tiberius B.v is a lavish volume containing computistical, astronomical, genealogical, regnal and geographical material in Latin and Old English, accompanied by rich illuminations including the mappa mundi and a Macrobian zonal map (29r, fig. 2): a celestial map

\footnotetext{
${ }^{1}$ The digitized manuscript is available to view on the British Library website:

<http://www.bl.uk/manuscripts/FullDisplay.aspx?ref=Cotton_MS_Tiberius_B_V/1> [accessed 28 March 2018]. All translations are my own unless otherwise stated.

2 P. Barber, 'Medieval Maps of the World', The Hereford World Map: Medieval World Maps and Their Context, ed. P. D. A. Harvey (London, 2006), pp. 1-43 (at 4); D. N. Dumville, 'The Anglian Collection of Royal Genealogies and Regnal Lists', ASE 5 (1976), 23-50, at 26-7; H. Gneuss and M. Lapidge, Anglo-Saxon Manuscripts: a Bibliographical Handlist of Manuscripts and Manuscript Fragments Written or Owned in England up to 1100 (Toronto, 2014), pp. 297-9; N. R. Ker, Catalogue of Manuscripts Containing Anglo-Saxon (Oxford, 1957), pp. 255-6; P. McGurk, 'Palaeography and Illumination', An Eleventh-Century Anglo-Saxon Illustrated Miscellany: British Library Cotton Tiberius B.v Part I. Together with Leaves from British Library Cotton Nero D.ii, ed. P. McGurk, D. N. Dumville, M. R. Godden and A. Knock, EEMF 21 (Copenhagen, 1983), pp. 28-39 (at 33).
} 
was also once present, but is now lost. ${ }^{3}$ The pairing of detailed world map and zonal map in the same manuscript is fairly common, but the zonal map, like the mappa mundi, is independent of the manuscript texts and unusual in its design. ${ }^{4}$

Critics have struggled to account for the manuscript's eclectic contents and structure. Evelyn Edson terms it a computus manuscript, although large amounts of the material only tangentially relates to computus. ${ }^{5}$ Other critics have focused more on the manuscript's worldview; Kathy Lavezzo argues that the presence of texts such as the Itinerary of Archbishop Sigeric gives a strong focus on Rome, while Nicholas Howe termed Tiberius B.v a 'book of elsewhere' because of its interest in spaces outside England. ${ }^{6}$ While Tiberius B.v is undeniably a manuscript engaged with the rest of the world, both Lavezzo and Howe neglect to place sufficient emphasis on the material connected to England, such as the genealogies. Tiberius B.v is a book of Rome and Anglo-Saxon England, of elsewhere as viewed from, connected with and of interest to here, and we can see this perspective reflected in its mappa mundi.

The mappa mundi was originally bound immediately preceding Priscian's Latin geographical text, the Periegesis, the incipit of which reads:

Incipit liber Pergesis, id est de situ terrae Prisciani grammatici urbis Romae Caesariensis doctoris quem de priscorum dictis excerpsit ormistarum sed et huic operi de tribus partibus uidelicet Asia Africa Europa mappam depinxerat

\footnotetext{
${ }^{3}$ McGurk 'Palaeography and Illumination’, p. 30. The principal contents are: a computistical miscellany including the labours of the months and the Metrical Calendar of Hampson (fols. 2r-19r); lists of popes, roman emperors, and English bishops (fols. 19v-22r); Anglo-Saxon royal genealogies (fols. 22r-3v); lists of Glastonbury abbots and tenth-century popes (f. 23v); the Itinerary of Archbishop Sigeric (fols. 23v-4r); Ælfric, De temporibus anni (fols. 24r-8v); Macrobian zonal map (f. 29r); three astronomical texts (fols. 30r-2r); Cicero, Aratea (fols. 32v-49v); astronomical excerpts (fols. 49v-54v); mappa mundi (f. 56v); Metrical Life of St Nicholas (fols. 55r-6v, 73r-v and 77r); Priscian, Periegesis (fols. 57r-73r); Wonders of the East, in Latin and Old English (fols. 78v-87v), notes relating to Battle Abbey (fols. 88r-v). A detailed list of contents is given by P. McGurk: 'Introduction: Contents of the Manuscript', Eleventh-Century Anglo-Saxon Illustrated Miscellany, pp. 15-24. The manuscript became disordered prior to the twelfth century. McGurk 'Palaeography and Illumination', pp. 28-30. A detailed study of the map in its manuscript context forms the basis of a recently completed doctoral thesis, 'The Anglo-Saxon Cotton Map in Context’ by M. Tedford, Queen’s University Belfast.

${ }^{4}$ McGurk 'The Macrobian Zonal Map', Eleventh-Century Anglo-Saxon Illustrated Miscellany, pp. 656; E. Edson, 'World Maps and Easter Tables: Medieval Maps in Context', Imago Mundi 48 (1996), 2542, at 35; A. Hiatt, 'The Map of Macrobius before 1100', Imago Mundi 59 (2007), 149-76, at 170, n. 46. On the way both Tiberius B.v maps problematize standard schemes, see: E. Edson, 'Isidore, Orosius, and the Medieval Image', Cartography in Antiquity and the Middle Ages, ed. R. J. A. Talbert and R. W. Unger (Leiden, 2008), pp. 219-36 (at 220, n. 5). The detail and structure of oecumene on the zonal map has parallels in the more sophisticated Ripoll map (Vatican City, Biblioteca Vaticana, Reg. lat. 123, fols. $143 \mathrm{v}-4 \mathrm{r}$, s. $\mathrm{x}^{\mathrm{med}}$ ), which has Carolingian connections. The Ripoll map is accompanied by a map of the heavens, as the Tiberius B.v zonal map once was. E. Edson, Mapping Time and Space: How Medieval Mapmakers Viewed Their World (London, 1997), pp. 80-6.

${ }^{5}$ Edson, 'World Maps and Easter Tables’, p. 32; Edson, Mapping Time and Space, pp. 74-80.

${ }^{6}$ N. Howe, Writing the Map of Anglo-Saxon England: Essays in Cultural Geography (New Haven, 2008), p. 154; K. Lavezzo, Angels on the Edge of the World: Geography, Literature, and English Community, 1000-1534 (Ithaca, NY, 2006), p. 28.
} 
aptam in qua nationum promontoriorum fluminum insularumque situs atque monstrorum formatur honeste. ${ }^{7}$

But while the mappa mundi does serve to illustrate the inhabited world described in the Periegesis, it is not related to that work in its drafting, nor to any other text within the manuscript. ${ }^{8}$ As Edson suggests: 'it seems most likely that the scribes felt a map would be appropriate and simply copied one they had at hand' ${ }^{9}$ Edson also observes that unlabelled features indicate it could have been copied from a larger wall-map. ${ }^{10}$ Peter Barber has suggested that this larger exemplar may have been at Glastonbury. ${ }^{11}$ Large-scale wall-maps are far less likely to survive than smaller examples bound into manuscripts - many are known only from descriptions - so one cannot conclude that the lack of other mappae mundi surviving from Anglo-Saxon England means such objects did not exist.

Although very few Anglo-Saxon maps survive, there is evidence for reasonable knowledge of visual cartography in Anglo-Saxon England. The extant cartographic corpus is diverse: as well as the two maps in Tiberius B.v, there are plans derived from Adomnán associated with Bede’s De locis sanctis, world diagrams with Bede's De natura rerum and De temporum ratione, and the spectacular plan of the tabernacle in the Codex Amiatinus. ${ }^{12}$ Martin Foys has argued that the fragment of an uncompleted mappa mundi in Cambridge, Corpus Christi College 265 (Worcester, $\mathrm{s} . \mathrm{xi}^{2}$ ) belongs to a family of maps found in later copies Byrthferth of Ramsey’s work,

\footnotetext{
7 'Here begins the book, "Periegesis", by Priscian, grammarian of the city of Rome, professor of Caesarea (Africa), that is about the situation of the earth, gathered by him from the writings in ancient world maps; and to this work of three arts, that is to say, Asia, Africa, and Europe, there is painted a suitable (aptam) map in which the location of nations, mountains, rivers, islands, and also wonders are accurately arranged.' British Library, MS Cotton Tiberius B.v., f. 57r. Transcription and translation from Edson, Mapping Time and Space, pp. 75-6.

${ }^{8}$ P. McGurk, 'The Mappa Mundi', Eleventh-Century Anglo-Saxon Illustrated Miscellany, pp. 79-87 (at 79). Intriguingly a catalogue of Glastonbury manuscripts from $1247 / 8$ lists another manuscript combining the Periegesis with a mappa mundi: 'Priscianus gramaticus de situ et nominibus terrarum cum mappa mundi' ('Priscian the Grammarian: the situation and names of the world with a mappa mundi'). English Benedictine Libraries: The Shorter Catalogues, ed. R. Sharpe, J. P. Carley, R. M. Thomson and A. G. Watson, Corpus of British Medieval Library Catalogues (London, 1996), p. 188, B. 39. 169. As Tiberius B.v contains south-western material including the Metrical Calendar of Hampson and a list of Glastonbury abbots (or, as Foot suggests, a memorial list), they may be related. S. Foot, 'Glastonbury's Early Abbots', The Archaeology and History of Glastonbury Abbey: Essays in Honour of the Ninetieth Birthday of C. A. Ralegh Radford, ed. L. Abrams and J. P. Carley (Woodbridge, 1991), pp. 163-90.

${ }^{9}$ Edson, 'World Maps and Easter Tables', p. 35. See also E. Edson, Mapping Time and Space, p. 76.

${ }^{10}$ Edson, 'World Maps and Easter Tables', p. 32; Edson, Mapping Time and Space, p. 76.

${ }^{11}$ Barber, 'Medieval Maps of the World', p. 4; P. Barber, 'Updating the Roman World', in Mapping Our World: Terra Incognita to Australia (Canberra, 2014), pp. 24-5 (at 25).

${ }^{12}$ See P. D. A. Harvey, 'Maps in the Age of Bede', Jarrow Lecture (2006). On Bede and the Codex Amiatinus image: C. O’Brien, Bede's Temple: An Image and Its Interpretation (Oxford, 2015), pp. 90100.
} 
suggesting the original template was Anglo-Saxon England. ${ }^{13}$ Two Old English prose texts, The Letter of Alexander to Aristotle and Wonders of the East, show awareness of cartographic perspective. In The Letter of Alexander Alexander desires to see ‘ða wynstran dælas Indie' and Wonders describes how: 'On pam wynstran dæle pæt rice is be ða deor on beop Catinos ... \& panan fram pam wynstran dæle syndan manege cyningas' ${ }^{14}$ Here space is viewed from above, as on a map. These Old English works are translations of Latin source texts, from which they derive this perspective: 'sinistram partem indiæ' in the Epistola Alexandri and 'In sinistra parte regio est Catinorum ... a sinistra parte sunt reges conplures' in De Rebus in Oriente Mirabilibus. ${ }^{15}$ That the Old English translators felt no need to change these phrases suggests awareness of cartography. In contrast, in the geographical section of the Old English Orosius, a translation of Paulus Orosius's fifth-century Latin work Historiarum adversum Paganos Libri Septem (Seven Books of History Against the Pagans), the Latin terms sinster and dexter are replaced by compass directions. ${ }^{16}$ For example, Old English Orosius I.i 'Be supan pæm mupan wið pone garsecg is se port pe mon hæt Caligardamana' renders 'a sinistra promunturium Caligardamana’ from Historiarum adversum Paganos 1.2.13. ${ }^{17}$ These alterations produce the lateral worldview typical of Old English texts, but reveal that the translator understood the cartographic 'god's-eye-view' perspective well enough to alter it. Cartography must have been more established in Anglo-Saxon England than the limited survival indicates, and as the mappa mundi suggests, it was not merely imitative: while heavily influenced by Carolingian models, it presents a distinctly Insular worldview.

\footnotetext{
${ }^{13}$ M. K. Foys, ‘An Unfinished Mappa Mundi from Late-Eleventh-Century Worcester’, ASE 35 (2006), 271-84.

14 'the left part of India'; 'in the left part of that kingdom are the wild beasts that are catinos ... and thence, from the left part, are many kings'. Three Old English Prose Texts in MS Cotton Vitellius A.xv, ed. S. Rypins, EETS o.s. 161 (London, 1924), pp. 30 and 66.

15 'the left part of India'; 'in the left part of that kingdom are catinos ... in the left part there are many kings'. Ibid. pp. 90 and 106.

${ }^{16}$ J. Bately, 'Ohthere and Wulfstan in the Old English Orosius', in Ohthere's Voyages: a Late 9thCentury Account of Voyages Along the Coasts of Norway and Denmark and Its Cultural Context, ed. J. Bately and A. Englert (Roskilde, 2007), pp. 18-39 (at 22).

17 'to the south of the mouth of the river on the ocean is the port that men call Caligardamana'; 'to its left is the promontory of Caligadamana'. The Old English Orosius, ed. J. Bately, EETS s.s. 6 (London, 1980), p. 9, 1l. 23-4; Orosius: Seven Books of History against the Pagans, trans. A. T. Fear (Liverpool, 2010), p. 37; Paulus Orosius, Pauli Orosii Historiarum adversum Paganos Libri VII, ed. K.

Zangemeister, CSEL 5 (Vienna, 1882), p. 12.
} 


\section{DESCRIPTION OF THE MAP}

The Anglo-Saxon mappa mundi is notably rather independent of other cartographic traditions. In particular, it is unusually accurate concerning the shape and inhabitants of Northwestern Europe and offers an exceptionally exact depiction of the British Isles - not until the thirteenth-century work of Matthew Paris is a better representation made. ${ }^{18}$ The Anglo-Saxon mappa mundi is a rectangular, full-page map of the inhabited world orientated with east at the top. It depicts the three continents of the oecumene, Europe, Asia, and Africa, surrounded by the oceanus (the world ocean). The map shows a number of undulating mountains and ranges, coloured in green, and various seas, many of which are red. Straight province boundaries and wavy rivers are delineated in brown. Cities are dotted over the map, and a lion is drawn in Asia. The map has a reasonably comprehensive legend, although not all features are labelled. ${ }^{19}$ The legend is mostly Latin, but the scribe was accustomed to writing in Old English, as indicated by the use of the insular ' $g$ ' in the majority of city-names in Europe and the term ‘suð Bryttas' applied to Brittany. ${ }^{20}$

For all its individuality, the Anglo-Saxon mappa mundi was not produced ex nihilo: the map is a rather syncretic construction with material harvested from various traditions. Visual antecedents can only be a matter for speculation as the survival of Late Antique and early medieval cartography is so limited. P. D. A. Harvey has connected features, including the straight province boundary divisions in Africa, to Roman imperial mapping and the world map of Marcus Vipsanius Agrippa, while both Patrick McGurk and Peter Barber have suggested Carolingian influence. ${ }^{21}$ The map's legend is easier to trace. As Konrad Miller noted, the majority is derived from the geography of Orosius's Historiarum adversum Paganos. ${ }^{22}$ Other legends come from the Old Testament and the writings of Isidore. However, many names, particularly in Northwestern Europe, are unique, and the treatment of new information compared to inherited material is revealing. There are significant copying errors in

\footnotetext{
${ }^{18}$ P. D. A. Harvey, Medieval Maps (London, 1991), pp. 10 and 21.

${ }^{19}$ For a transcription of the legend see: McGurk, 'The Mappa Mundi', pp. 86-7.

20 'south Britons'. P. D. A. Harvey, Mappa Mundi: the Hereford World Map (Toronto, 1996), p. 27; McGurk, 'The Mappa Mundi', p. 79.

${ }^{21}$ Barber, 'Medieval Maps of the World’, p. 5; Harvey, Medieval Maps, p. 21; McGurk, 'The Mappa Mundi', p. 86. Reused elements of Roman imperial mapping are relatively common in medieval cartography, see: P. Gautier Dalché, 'L’héritage antique de la cartographie médiévale: les problèmes et les acquis', Cartography in Antiquity and the Middle Ages: Fresh Perspectives, New Methods, ed. R. J. A. Talbert and R. W. Unger (Leiden, 2008), pp. 29-66 (at 41).

${ }^{22}$ K. Miller, Mappaemundi: die ältesten Weltkarten (Stuttgart, 1895-8), III (1895), p. 35. Reiterated by C. R. Beazley: 'New Light on Some Mediæval Maps', Geog. Jnl 15 (1900), 130-41, at 134.
} 
Asia and Africa, contrasting strongly with the detail and accuracy of its depiction of Northwestern Europe. ${ }^{23}$

The map's focus is not on Rome, which is only marginally further from the edge of the world than London, nor on Jerusalem, as is common in later mappae mundi - this map emphasizes the scale of the world. Like the much simpler eighthcentury Albi map (Albi, Bibliothèque municipale, MS 29, f. 57v), the Anglo-Saxon mappa mundi centres on the Mediterranean Sea rather than a city, although numerous cities of various sizes are illustrated. There is no sense that any one city is the most prominent in the inhabited world, although Babylon, Tarsus, Constantinople, Rome, Ravenna, Carthage, Tingis, Jerusalem, and Alexandria are on an impressive scale. While many of these cities are clustered around the Mediterranean, the urbanized area extends from Babylon in the east to Armagh in the west. Although this reproduces the perspective of the Roman Empire, with the world centred on the Mediterranean, there is a real sense of the breadth; myriad islands and scattered cities serve to ensure that the map presents many regional centres, and no one place appears as the most significant. There is a more generous allowance of sea than is typical of mappae mundi, and the coastline is unusually detailed, with many islands. ${ }^{24}$ The map impresses the scale of bodies of water, particularly the Mediterranean and the seas surrounding Britain and Scandinavia. The unusual rectangular shape allows for a larger and more definite border of oceanus than is conventional in medieval cartography: all the lands are firmly within the compass of the world rather than perilously on the margin. As on the Macrobian map which accompanies the mappa mundi in Tiberius B.v, the Pillars of Hercules appear in the west, and are the only thing on the absolute margin: they act as a gateway to the known world, creating a distinct separation of real and imagined geography; beyond them is the unknown, and that is beyond the scope of this map. ${ }^{25}$

The Anglo-Saxon map lacks the obvious religious or devotional intent typical of later mappae mundi. ${ }^{26}$ This secular focus connects the Anglo-Saxon map to what is

\footnotetext{
${ }^{23}$ See McGurk 'The Mappa Mundi’, p. 85. For discussion and interpretation of the more corrupt parts of the legend see W. L. Bevan and H. W. Phillott, Medieval Geography: an Essay in Illustration of the Hereford Mappa Mundi (London, 1873), pp. xxxiv-vi.

${ }^{24}$ Ibid. p. xxxiv.

${ }^{25}$ Their appearance in this location is rather like the pillared gates between heaven, Eden and the world in the illustrations to Oxford, Bodleian Library, MS Junius XI.

${ }^{26}$ Cf. the thirteenth-century Psalter, Ebstorf and Hereford world maps. The Psalter Map (London, British Library, Add. 28681, f. 9r. c. 1265) shows Christ above the world, the Ebstorf Map depicts Christ encompassing the world with his hands and feet, while the Hereford map (c. 1285) depicts
} 
known of Carolingian cartography: Patrick Gauter Dalché has argued for the use of cartography in the schoolroom to illuminate place names encountered in other texts, and Marcia Kupfer has highlighted references to mappae mundi in library catalogues alongside other kinds of secular knowledge. ${ }^{27}$ Kupfer notes that the various groupings suggest that geography, an adjunct to history, belonged to a realm of secular knowledge made available through the study of liberal arts'. ${ }^{28}$ Religious interpretations could be derived from the manner in which the map was framed, as the diachronic events of world history, recorded synchronously by the map in visual form, could be given a spiritual narrative through typological readings. Although the map's focus is generally secular, scripture is used as a source. The tribes of Israel are allocated areas and the locations of God's covenants with man on Sinai and Ararat are marked, the latter with a small drawing of the Ark. The Red Sea is coloured red on the map, and the Israelites' route through it is indicated, but as the other seas and great rivers of Africa and the Middle East are also red there is no obvious focus on the Exodus representation. Bede, in De natura rerum §42, attributes the redness of the Red Sea to the surrounding lands being rich in red pigments. The idea that the soil was responsible may be why the Anglo-Saxon mappa mundi colours all large-scale African and Middle Eastern waters red. ${ }^{29}$ Unlike many medieval mappae mundi, particularly those of the Beatus group, the Anglo-Saxon map does not offer an earthly location for paradise - the island in the east is not Eden but Taprobane (Sri Lanka). ${ }^{30}$ New Testament figures and angels are absent. The results of God's historical interventions in the landscape are shown, but there is no divine presence. Like later mappae mundi which, as Foys observes, 'serve as anthologies of both time and space,

judgement day in its margin, along with the letters $\mathrm{M}, \mathrm{O}, \mathrm{R}$ and $\mathrm{S}$, serving to highlight the transience of the world. Corresponding to their differing messages, Ebstorf shows the risen Christ in Jerusalem, Hereford the crucifixion. The Hereford Map also depicts a human act of measuring - Emperor Augustus ordering his survey of the world.

${ }^{27}$ P. Gautier Dalché, La 'Descriptio mappae mundi' de Hughes de Saint-Victor (Paris, 1988), pp. 95100; M. Kupfer, 'Medieval World Maps: Embedded Images, Interpretive Frames', Word \& Image 10 (1994), 262-88, at 264.

${ }^{28}$ Ibid. p. 264.

${ }^{29}$ Bede, On the Nature of Things and On Times, trans. F. Wallis (Liverpool, 2010), p. 96. Orosius I.28 describes the origin of the Nile (depicted on the map according to his description as a wide red swathe running westwards through Africa, before turning north to the Mediterranean) as apparently being in the Red Sea. Maris rubris can refer to all of the Indian Ocean in Classical geography, but the AngloSaxon mappa mundi extends the red colour even further.

${ }^{30}$ A-D. von den Brincken, 'Jerusalem on Medieval Mappaemundi: a Site Both Historical and Eschatological’, in The Hereford World Map, ed. P. D. A. Harvey (London, 2006), pp. 355-79, at 362 and 375. Pliny, in Historia naturalis VI:xxii, describes Taprobane as a bountiful, peaceful place and records its discovery to be an island, not another world, by Alexander the Great. C. Plinius Secundus, Naturalis Historia Libri XXXVII, ed. K. T. F. Mayhoff, 6 vols. (Leipzig, 1854-1865), I (1854), 234-5. 
collapsing diachronic representations of geography and history into a single synchronic plane', the Anglo-Saxon map is interested in a synchronic representation of history, but this is the history of tribes and empires, rather than salvation. ${ }^{31}$ Like the Carolingian maps discussed by Kupfer, the Anglo-Saxon map represents the world 'imbricated in and limited by temporality'. ${ }^{32}$ The map shows physical geography, but the spiritual, supernatural gloss on the space that dominates the visual message of complex thirteenth-century maps is beyond the world of this mappa mundi.

The monstrous races, which so often populate the margins of medieval maps, are given minimal attention. The Anglo-Saxon mappa mundi appears, despite the incipit to the Periegesis's promise that it depicts monstra, relatively disinterested in such mirabilia. The legend contains very few marvellous places, and those that do appear, such as the Mons Aureus in the distant East, are located according to information provided by classical authorities and labelled in the same manner as verifiable geography. The unusually long legend for what appears to be a volcano in Eastern Africa reads 'Hie dicitur esse mons semper ardens', injecting a note of uncertainty and acknowledging the distance from primary information. ${ }^{33}$ The few marvellous places and dubiis homines present on the map are represented only by text; the mangled legend about the 'bestiis et serpentibus' in Africa appears to derive from the discussion of wondrous animals in Isidore's Etymologiae, but no creatures are drawn. ${ }^{34}$ Gog and Magog are named in Asia, and the cynocephali in the extreme south of Africa, but they are not depicted. The style of their legends corresponds to those employed for tribes of people, deemphasizing their monstrosity. The griffins of Asia are even transformed into 'Griphorum gens'. ${ }^{35}$ Other legends in Africa may also refer to marvels, but they are carelessly copied and corrupt, suggesting a lack of interest in this region. The only creature properly illustrated is a lion, accurately located in Asia and appended with the simple legend 'hic abundant Leones' ${ }^{36}$ The lion demonstrates that the draftsman of the map did not lack a flair for illustrating

\footnotetext{
${ }^{31}$ Foys, 'An Unfinished Mappa Mundi', p. 5. For a thorough analysis of their blending of geography and history see: D. Woodward, 'Reality, Symbolism, Time, and Space in Medieval World Maps', Annals of the Assoc. of Amer. Geographers 75 (1985), 510-21.

32 Kupfer, 'Medieval World Maps', p. 265.

33 'This is said to be the ever-burning mountain'.

${ }^{34}$ Isidore, The Etymologies of Isidore of Seville, ed. S. A. Barney (Cambridge, 2006), p. 293, XIV.v.15.

35 'Griffon nation'.

36 'Here lions abound'.
} 
creatures, but they have indulged it nowhere else. Only the tiny picture of the Ark shows any visual story telling - other illustrations are of cities, inland seas and mountains. ${ }^{37}$ The map's putative exemplar may have been more vividly illustrated, but lack of space does not seem an adequate explanation for the lack of living creatures. Rather, the lion seems to fill a space on the map that lacked the cities and geographical legends that occupy the rest of the space; he fills in what would otherwise be blank, suggesting human habitations are the map's priority, not marvels.

The map's principal focus is the representation of coastlines, islands, and urban centres. Cityscapes are the predominant sign of human society on the map and reveal the regional bias in its drafting. Cities, as on the smaller Macrobian map, are depicted in plan and elevation as enclosures with varying numbers of turrets. ${ }^{38}$ The largest, most complex drawings represent Rome in the west and Babylon in the east. Most of the map's cities are widely spaced, but several are concentrated in Italy and the British Isles. ${ }^{39}$ The rationale behind the cities selected for representation is not religious significance; the scale of Babylon, Alexandria, Carthage, and Rome reveals an interest in the Orosian conception of the four empires of the world (Babylonia and Media, Macedonia, Carthage, and Rome), while the inclusion of London indicates a focus on new centres of power, trade and wealth, as well as an Anglo-centric view. The regional bias is also evident in the extremely detailed depiction of the British Isles, with the Orkney Islands in the north, what is probably the Isle of Man in the west, and the Cornish Peninsular in the south.

\section{BRITAIN IN THE INHABITED WORLD}

The geography represented on the Anglo-Saxon Map can be seen as an expression of later-Anglo-Saxon interests in the arrangement of space and power. The cartographic structure of the map denies the importance of centrality, suggesting that a margin/centre dichotomy was not a concern of the mapmaker. The map presents the inhabited world as consisting of islands, cities and the spaces in between. The lack of attention to absolute margins, combined with the centrality of the sea, reveals that this

\footnotetext{
${ }^{37}$ What initially appears to be a simplistic drawing depicting two stickmen fighting in the Cornish peninsular is more likely to be a roughly sketched town such as Exeter or perhaps Glastonbury. ${ }^{38}$ Two square towns (probably Rome [or Constantinople?] and Jerusalem) appear on the Macrobian zonal map (29r). The western town is depicted as enclosing two carefully individuated human heads: one blonde, the other brunette - perhaps denoting Romulus and Remus.

${ }^{39}$ Although quite small, Winchester and Armagh appear similar to the smaller Italian cities. The drawing for London is not quite the same design.
} 
map presents a worldview aligned with Anglo-Saxon perceptions of space, based on the experience of inhabiting an island. For island-dwellers the sea is an important routeway, in contrast to the continental way of thinking about the world in which the oceanus is a barrier, and the people who live in it are the inhabitants of almost another world.

The prominence and civilized nature of the northwest on the Anglo-Saxon mappa mundi is in marked contrast to the typical depiction of the region in Late Antique and early medieval geographic writings, which frequently describe northern Europe, and the British Isles in particular, as being at the absolute limits of the world. ${ }^{40}$ As Fabienne Michelet notes, in the Classical tradition there is conventionally a gradation towards savageness the farther one moves from the civilized centre. This traditional image remained current in early medieval texts. ${ }^{41}$ For authors writing from a continental perspective and confidently occupying the centre of the civilized world, the edges were remote, and the people occupying them barbarous and decidedly other - an attitude expressed towards the occupants of the British Isles. The third-century Latin geographer Solinus, whose work was known in Anglo-Saxon England, states in his De mirabilibus mundi that (XXII): 'Finis erat orbis ora Gallici litoris, nisi Brittania insula non qualibet amplitudine nomen paene orbis alterius mereretur', before describing the barbarian occupants of Britain and Ireland. ${ }^{42}$ This perception of the location of Britain persisted beyond the period of Anglo-Saxon settlement. Gregory the Great, in a letter of 598 to Eulogius, Bishop of Alexandria describing the Augustinian mission writes:

... quia, dum gen Anglorum in mundi angulo postie in cultu lignorum ac lapidum perfida nuncusque remaneret, ex vestrae mihi oratonis adiutoro placuit, ut ad eam monasterii mei monachum in praedicatione transmitter Deo auctore debuissem. Qui data a me licentia a Germaniarum episcopis episcopus factus cum eorum quoque solaciis

\footnotetext{
${ }^{40}$ The Periegesis, which claims the map as its illustration, offers only vague details about northern Europe. See further Edson, Mapping Time and Space, p. 76.

${ }^{41}$ F. Michelet, 'Centrality, Marginality and Distance: Britain's Changing Location on the Map of the World', The Space of English, ed. D. Spurr and C. Tschichold (Tübingen, 2005), pp. 51-68, at 51-2. Cf. the Ebstorf map on which monstrous races occupy the entire southern edge, and the Hereford mappa mundi on which they are found around the margins, predominantly in the south, but also in northern regions.

42 'The sea coast of Gaul should be the end of the world, but that the island of Britain, for the largeness thereof, merits the name of almost another world'. Solinus, C. Ivlii Solini Collectanea Rerum Memorabilium, ed. T. Mommsen (Bern, 1895), pp. 99-100. On knowledge of this text in Anglo-Saxon England see M. Lapidge, The Anglo-Saxon Library (Oxford, 2006), p. 333.
} 
ad praedictam gentem in finem mundi perductus est (VIII.29, 27$32) .{ }^{43}$

For Gregory, Britain is a nation at the end of the world. Educated Anglo-Saxons were all too aware that their home was located in a region understood by others as marginal. Bede, writing in the early eighth century, reproduces the perspective of his British source, Gildas, who in turn echoes Pliny the Elder's Historia naturalis IV.30. Gildas writes: 'brittannia insula in extremo ferme orbis limite circium occidentemque'. ${ }^{44}$ Bede modifies this in Historia ecclesiastica I.i to 'Brittania Oceani insula ... inter septentrionem et occidentem locata est' and emphasizes Britain's distance from Europe. ${ }^{45}$ Bede's use of the term oceanus suggests that he thought of Britain as belonging to the limits of the world in geographical terms. However, by the end of King Alfred's reign in the late ninth century, England was no longer as remote from the centre, particularly in light of the growing power of Scandinavia, which affected England directly through the Danelaw. ${ }^{46}$

\section{TRADE, URBANISATION AND THE MAPPA MUNDI}

The Anglo-Saxon mappa mundi's attention to Scandinavia and London can be seen as a visual expression of the geopolitical interests of later Anglo-Saxon England, from the reign of Alfred onwards. Trade with Scandinavians was used by Alfred to buffer England against the Danelaw by promoting peace and cooperation. Cap. 5 of King Alfred's treaty with Guthrum contains specific reference to the necessity of achieving freedom of movement for the purposes of trade while maintaining national identity. ${ }^{47}$

\footnotetext{
43 ،... for while the nation of the Angli, placed in a corner of the world, remained up to this time misbelieving in the worship of stocks and stones, I determined, through the aid of your prayers for me, to send to it, God granting it, a monk of my monastery for the purpose of preaching. And he, having with my leave been made bishop by the bishops of Germany, proceeded, with their aid also, to the aforesaid nation that is at the end of the world'. Gregory, Gregorii I Papae Registrum Epistolarum. Tomus II, Libri VIII-XIV cum Indicibus Et Praefatione, ed. P. Ewald and L. M. Hartmann, MGH Epistolae 1-2 (Bern, 1887-99), II (1899), 30.

44 'The island of Britain lies virtually at the end of the world, towards the west and north-west'. Gildas, The Ruin of Britain and Other Documents, ed. and trans. M. Winterbottom (London, 1978), pp. 89 and 16.

45 'Britain, an island in the ocean ... is situated between the north and west'. Bede, Bede's Ecclesiastical History of the English People, ed. and trans. B. Colgrave and R. Mynors (Oxford, 1969), p. 15.

${ }^{46}$ The archaeological record shows that in this period a number of places originally founded as forts became towns with a corresponding increase in trade: A. Vince, 'Saxon Urban Economies: An Archaeological Perspective’, Environment and Economy in Anglo-Saxon England, ed. by J. Rackham (York, 1994), pp. 108-19, at 112. By the Norman Conquest England was one of the most urbanized areas of Europe with at least $10 \%$ of the population residing in towns: P. H. Sawyer, From Roman Britain to Norman England (London, 1978), p. 204.

${ }^{47}$ The Laws of the Earliest English Kings, ed. F. L. Attenborough (Cambridge, 1922), p. 100.
} 
Provision is made to ensure that there can be the same guarantees as under English laws, and as Susan E. Kruse notes, the focus is neutral trade, not ritual exchange. ${ }^{48}$ The Law code issued by King Edward and King Guthrum shows that a close cooperation with regard to trade legislation developed between England and the Danelaw. ${ }^{49}$ This cultivation of trade is politically shrewd: mutual economic dependency encourages stability. ${ }^{50}$ This increase is trade is tied to an increase in urbanisation. The A-Text of the Anglo-Saxon Chronicle for 886 states: 'Dy ilcan geare gesette Elfred cyning Lundenburg, \& him all Angelcyn to cirde pæt buton deniscra monna hæftniede was; \& hie pa befæste ba burg Eperede aldormen to haldonne'. ${ }^{51}$ The re-foundation of the city of London after Alfred's treaty with Guthrum is strongly linked to the development of a trade economy, particularly around water-based traffic utilizing London's port facilities. The historical record shows London developing as a port; a grant of 898/9 to the Bishop of Worcester and the Archbishop of Canterbury records their right to moor ships where the Thames ran alongside their properties just outside the walls. ${ }^{52}$ This charter, S 1628, strongly suggests that commercial activity was taking place in the city, demonstrating the link between urbanisation and the trade economy. The securing of trade within the city was matched by the construction of a fortification at Southwark, as Simon Keynes notes, 'effectively commanding passage along the river' and controlling the trade route. ${ }^{53}$ The success of London as a port is shown by the shift from the export of only luxury goods in the seventh and eighth centuries, to a trade in bulkier commodities in

\footnotetext{
${ }^{48}$ E.g. Alfred's cap. 34 which makes provision for traders going up into the country to appear before the Reeve to be approved, and builds on Ine 25's demand that traders have witnesses. S. E. Kruse, 'Trade and Exchange across Frontiers', Silver Economy in the Viking Age, ed. by J. Graham-Campbell and G. Williams (London, 2007), pp. 163-76, at 165.

${ }^{49}$ For example, cap. 7 is concerned with trade and labour and begins 'Sunnandæges cypinge gif hwa agynne, polie pæs ceapes \& twelf orena mid Denum \& XXX scillinga mid Englum' (If anyone sells on a Sunday, he shall lose the goods and twelve ores in a Danish district and thirty shillings in an English district). Laws of the Earliest English Kings, ed. Attenborough, p. 106.

${ }^{50}$ For further discussion of the shift in trade to Scandinavia and the relationship between commerce and royal wealth see: J. R. Maddicott, 'Trade, Industry and the Wealth of King Alfred', Past \& Present 123 (1989), 3-51.

51 'That same year King Alfred restored London, and all England turned to him, excepting that captured by the Danish men: and he committed that burh to Alderman Æthered to hold'. The AngloSaxon Chronicle: A Collaborative Edition, MS. A, ed. J. Bately (Cambridge: D. S. Brewer, 1986). ${ }^{52}$ Although the charter only survives in later copies it is regarded as authentic. See: D. Hooke, 'Uses of Waterways in Anglo-Saxon England', Waterways and Canal-Building in Medieval England, ed. by J. Blair (Oxford, 2007), pp. 37-54, at 40-1.

${ }^{53}$ S. Keynes, 'King Alfred and the Mercians', Kings, Currency and Alliances: History and Coinage of Southern England in the Ninth Century, ed. M. A. S. Blackburn and D. N. Dumville (Woodbridge, 1998), pp. 1-46, at 24.
} 
the eleventh, characteristic of a more trade-based economy. ${ }^{54}$ This success is reflected in London's depiction on the mappa mundi.

London was not the only site of development. The law codes, especially laws related to trade in towns, provide evidence of the expansion of urban areas. While the laws of Ine and Alfred regulate for trade in the countryside, those of Edward the Elder reveal the rising importance of urban space: Cap. 1 states that 'nan man ne ceapige butan porte', although provision is made for warrantors for trading elsewhere, indicating that the old system was still partly operational. ${ }^{55}$ The laws of Æthelstan represent the culmination of the change; in the second law code of his reign Caps 1214 make explicit the central role of the town: only towns are permitted a mint, they must be maintained yearly, and 'ælc ceaping sy binnon port'. ${ }^{56}$ Archaeological evidence also shows crafts becoming focused in urban areas; for example the midtenth to mid-eleventh century shows a change from rural production of pottery to an urban manufacturing base, with traffic between burhs and from burhs to the countryside. ${ }^{57}$ The increased importance of urban space and trade in later AngloSaxon England are reflected in the mappa mundi's general interest in cities.

It is not only in the representation of urban space that the influence of trade may be perceived on the Anglo-Saxon mappa mundi. The depiction of the physical geography of Northwestern Europe owes much to the trading culture of the ninth and tenth centuries. The period of urban development in Anglo-Saxon England coincided with the waning of the Carolingian Empire: new opportunities emerged as Carolingian ports declined. ${ }^{58}$ The growth of Scandinavian centres such as Hedeby in Southern Jutland is marked during the ninth and tenth centuries. ${ }^{59}$ The rise of

\footnotetext{
${ }^{54}$ Sawyer, From Roman Britain to Norman England, pp. 231-2.

55 'no one shall trade except in a market town'. The Laws of the Earliest English Kings, ed. Attenborough, p. 114. Cf. Laws of Ine, cap. 25 and Alfred cap. 34. Ibid. pp. 44 and 78.

56 ‘all trading shall be carried out in a town'. Ibid. p. 134. Athelstan's decree does not seem to have had long-term success: Cnut decreed that trade required the presence of witnesses regardless of where it was carried out. See Cnut II.24: The Laws of the Kings of England from Edmund to Henry I, ed. A. J. Robertson (Cambridge, 1925), p. 186. Yet Edgar's legislation for boroughs does indicate that the greatest provision of witnesses was to be found in towns, cf. IV Edgar cap. 3. 1-5: Ibid. pp. 32-4; H. Loyn, 'Towns in Late Anglo-Saxon England: The Evidence and Some Possible Lines of Enquiry', England before the Conquest: Studies in Primary Sources Presented to Dorothy Whitelock, ed. P. Clemoes and K. Hughes (Cambridge, 1971), pp. 115-28, esp. 122-3.

${ }^{57}$ Vince, ‘Saxon Urban Economies’, p. 114.

58 T. Reuter, 'The End of Carolingian Military Expansion', Medieval Polities and Modern Mentalities, ed. J. Nelson (Cambridge, 2006), pp. 251-67.

${ }^{59}$ V. Hilberg, 'Hedeby in Wulfstan's Days: A Danish Emporium of the Viking Age Betwen East and West', Wulfstan's Voyage: The Baltic Sea Region in the Early Viking Age as Seen from Shipboard, ed. A. Englert and A. Trakadas (Roskilde, 2009), pp. 79-113; H. Jankuhn, Haithabu: ein Handelsplatz der Wikingerzeit, 8th edn (Neumünster, 1986).
} 
Scandinavia as a centre of power encouraged the development of a Northwestern European outlook in geographical works produced in later Anglo-Saxon England; this shift is exemplified by the Anglo-Saxon mappa mundi and by the geographical section of the Old English Orosius, which may have provided source material for the map.

\section{THE ANGLO-SAXON MAPPA MUNDI AND THE OLD ENGLISH OROSIUS}

Although Patrick McGurk has stated that connections between the Anglo-Saxon mappa mundi and the Old English Orosius 'would seem to be at the most indirect', they are nevertheless worthy of consideration, particularly for what they reveal about the worldview of later Anglo-Saxon England. ${ }^{60}$ In particular: the interest that the Old English Orosius has in translatio imperii, as highlighted by Francis Leneghan; its dependence on Frankish Orosian material, as shown by Malcolm Godden; its incorporation of new material on Scandinavia; and the reconfiguration of everything in light of West Saxon interests and ambitions echo what is seen in visual form on the mappa mundi. ${ }^{61}$ Both the Old English Orosius and the Anglo-Saxon mappa mundi are works in which Classical and Carolingian antecedents are given a new north-western perspective that asserts the power and influence of Anglo-Saxon England, particularly Wessex.

The Old English Orosius is a relatively free translation of Orosius's Historiarum adversum Paganos, produced in the period 870-930. ${ }^{62}$ Although traditionally associated with King Alfred, to whom William of Malmesbury attributed the work, the Old English Orosius is the product of several translators' labour and its precise origins are unknown. ${ }^{63}$ The Old English Orosius is indebted to Carolingian intellectual culture: Godden has revealed the translator's incorporation of material derived from Frankish glosses of the Latin text. ${ }^{64}$ The text survives in two manuscripts: the 'Tollemach Orosius', London, British Library, Additional 47967

\footnotetext{
${ }^{60}$ McGurk, 'The Mappa Mundi’, p. 86, n. 43.

${ }^{61}$ M. R. Godden, 'The Old English Orosius and Its Sources', Anglia 129 (2011), 297-320; F. Leneghan, 'Translatio imperii: The Old English Orosius and the Rise of Wessex', Anglia 133 (2015), 656-705.

${ }^{62}$ M. R. Godden, 'The Old English Orosius and Its Context: Who Wrote It, for Whom, and Why?', Quaestio Insularis 12 (2011), 1-30. The standard edition is: Old English Orosius, ed. Bately.

${ }^{63}$ See Bately, 'Ohthere and Wulfstan', pp. 21-2; J. Bately, 'The Spelling of the Proper Names in the OE Orosius: The Case for Dictation by a Welshman Revisited', JEGP 116 (2017), 45-81; E. M. Liggins, 'Syntax and Style in the Old English Orosius', Studies in Earlier Old English Prose, ed. P. E. Szarmach (Albany, 1986), pp. 245-74, at 268.

${ }^{64}$ Godden, 'The Old English Orosius and Its Sources'.
} 
(s. ${ }^{1}$, missing the second quire), and London, British Library, Cotton Tiberius B.i, fols. 3-111 (s.xi ${ }^{1}$, complete). ${ }^{65}$ There are also two fragments: Oxford, Bodleian Eng. Hist. e. 49 ( s.xi ${ }^{1}$ ), and Vatican City, Reg. lat. 497, f. 71 (s.xi). ${ }^{66}$ Given that the earliest surviving manuscript is a product of the early tenth century, Leneghan has recently suggested that the Old English Orosius can productively be read as speaking to the ambitions of England in that period through its interest in translatio imperii. The Anglo-Saxon mappa mundi represents very similar interests and reconfigurations in visual form, suggesting that its putative English exemplar had its origins in the same milieu.

The Old English Orosius edits, expands and reshapes its Latin source, reducing the attention to salvation history, and focussing instead on cities and empires - like the mappa mundi it has a relatively secular emphasis and a balanced interest in the world's powers. ${ }^{67}$ Leneghan sees this reshaping as reflecting ambitions to appropriate and emulate Carolingian power and culture, taking advantage of new opportunities created by Carolingian decline in the late ninth and early tenth century. ${ }^{68}$ The Anglo-Saxon mappa mundi can be seen as a product of the same intellectual climate, presenting England as part of imperial culture and signalling status through the cachet conferred by cartography. As Patrick Gautier Dalché observes, Charlemagne was strongly associated with cartography - Einhard describes silver maps of Constantinople, Rome and the whole universe bequeathed in Charlemagne's will (Vita Karoli Magni XXXIII) - especially as part of his programme of renovatio imperii, and it is possible that we have in the Anglo-Saxon mappa mundi an English attempt at emulation. ${ }^{69}$ Natalia Lozovsky highlights the Carolingians' intense interest in Roman geographical writing, and in translatio

\footnotetext{
${ }^{65}$ Old English Orosius, ed. Bately, pp. xxiii-lv; Gneuss and Lapidge, Anglo-Saxon Manuscripts, pp. 70, 227-8 and 94-5; Ker, Catalogue, pp. 91, 64-6 and 251-3.

${ }^{66}$ Old English Orosius, ed. Bately, pp. xxiii-lv; Gneuss and Lapidge, Anglo-Saxon Manuscripts, pp. 476 and 662-3; Ker, Catalogue, pp. 84 and 459.

${ }^{67}$ Godden, 'The Old English Orosius and Its Sources'; Leneghan, 'Translatio imperii', p. 680; E. Tyler, 'Writing Universal History in Eleventh-Century England: Cotton Tiberius B.i, German Imperial History-writing and Vernacular Lay Literacy', The Life of Universal Chronicles in the Middle Ages, ed. M. Campopiano and H. Bainton (Woodbridge, 2017), pp. 65-94.

${ }^{68}$ Leneghan, 'Translatio imperii'.

${ }^{69}$ Gautier Dalché, La 'Descriptio mappae mundi', pp. 122-3; P. Gautier Dalché, 'Les sens de mappa (mundi): IV ${ }^{\mathrm{e}}$-XIV $\mathrm{e}^{\mathrm{e}}$ siècle', Archivum latinitatis medii aevi 62 (2004), 187-202, at 188; Einhard, Vita Karoli Magni, ed. O. Holder-Egger and G. H. Pertz, MGH ss. rer. Germ. 25 (Hannover, 1911), p. 40; Barber, 'Medieval Maps of the World', p. 5.
} 
imperii from the Romans to the Franks. ${ }^{70}$ Like Lozovsky, Emily Albu has drawn attention to the importance of maps as symbols of power and control to Charlemagne and his successors, and the way in which 'Carolingian copyists and commentators repeatedly stressed intimate ties with the Roman drive to empire'. ${ }^{71}$ For both Rome and Francia mapping could be equated with control, and earlier representations of the history and geography of the world could be adjusted to serve contemporary interests, as Gautier Dalché has highlighted. ${ }^{72}$ In her study of the employment and adaptation of Roman geographical texts in the Carolingian empire, Lozovsky focuses on examples of selective excerpting and updating, including of Orosian material, to illustrate how inherited information was repurposed to serve Carolingian perspectives and interests. ${ }^{73}$ The changes that she highlights are reminiscent of those seen in the Old English Orosius, suggesting such texts held similar potential for Anglo-Saxons. Anglo-Saxons encountering Carolingian glosses and adaptions of Roman sources, as Godden suggests is the case with the Old English Orosius, may have been inspired to attempt a similar approach in order to present tenth-century England as heir to the Roman Empire, resulting in the reconfigurations seen in textual form in the Old English Orosius and visually on the mappa mundi. ${ }^{74}$

The mappa mundi's interest in the north-west of the inhabited world is reflected in the geographical section that opens the Old English Orosius. Book 1, Chapter 1 contains the most obvious insertion of non-Orosian material, presenting new information on the north, including the accounts of the voyages of two seafarers, Ohthere and Wulfstan, in northern Europe. ${ }^{75}$ The geographical section as a whole, and in particular these accounts, help to shed new light on the depiction of the north-west on the Anglo-Saxon mappa mundi. Unlike travel accounts and itineraries, which could be followed, medieval world maps were not primarily designed for navigation they simply provide information about the nature of the world according to the knowledge and ideology of the society that produced them. Yet travel accounts,

\footnotetext{
${ }^{70}$ N. Lozovsky, 'Roman Geography and Ethnography in the Carolingian Empire’, Speculum 81 (2006), 325-64.

${ }^{71}$ E. Albu, The Medieval Peutinger Map: Imperial Roman Revival in a German Empire (Cambridge, 2014), pp. 44 and 45. See also E. Albu, 'Imperial Geography and the Mediaeval Peutinger Map', Imago Mundi 57 (2005), 136-38.

${ }^{72}$ P. Gautier Dalché, ‘Tradition et renouvellement dans la représentation de l'espace géographique au IX ${ }^{\mathrm{e}}$ siècle', SM 24 (1983), 121-246.

${ }^{73}$ Lozovsky, 'Roman Geography and Ethnography'.

${ }^{74}$ Godden, 'The Old English Orosius and Its Sources'.

${ }^{75}$ Much of the new material (excluding Ohthere and Wulfstan) has an east Frankish perspective. Godden, ‘The Old English Orosius and Its Sources’, p. 316.
} 
navigational directions and geographical descriptions are necessarily interlinked with mappae mundi. Navigation accounts would have been crucial in allowing maps to progress from classical models. Given that the Anglo-Saxon mappa mundi's depiction of Britain and Scandinavia is unique in this period, sources other than Late Antique cartographic models must have been consulted for its drafting. It is probable that the north-western section of the Anglo-Saxon mappa mundi or its proposed source were, in part, drafted from seafarers' accounts such as those preserved in the Old English Orosius.

The addition of the two traders' accounts to the geographical section of the Old English Orosius creates a geographical and anthropological interest in the north not found in the Latin text. Alfred Hiatt describes their presence as creating a 'regional chorography' in contrast to the peripheral treatment of Scandinavia and north-west Europe in Classical and Late Antique geographic sources. ${ }^{76}$ The accounts are a curious addition, focusing on anthropology, commerce and trading empires, rather than merely the layout of the world, yet they contribute to the text's creation of an Anglo-Saxon worldview. The geographical section derived from the Latin simply describes the spatial relationship of countries, centring the world on the Mediterranean region. In the Old English Orosius new material is added on Europe north of the Danube, interrupting the account derived from Historiarum adversum Paganos 1.2 between Moesia (1.2.55) and Thracia (1.2.56), but it is presented in the same point-by-point style as the geography derived from the Latin text. The two travel narratives conclude the Northwestern European section, following the description of Scandinavia. They are stylistically very different, and the transition to them is rather abrupt:

Burgenden habbað pone sæs earm be westan him 7 Sweon be norban, 7 be eastan him sint Sermedbe, 7 be supan him Surfe. Sweon habbað be supan him pone sæs earm Osti 7 be eastan him Sermende, 7 be norpan him ofer pa westenne is Cwenland, 7 be westannorpan him sindon Scridefinne 7 be westan Norpmenn.

Ohthere sæde his hlaforde, Ælfrede cyninge, pæt he ealra Norðmonna norpmest bude. He cwæð pæt he bude on pæm lande norpweardum wip pa Westsæ. ${ }^{77}$

\footnotetext{
${ }^{76}$ A. Hiatt, 'Beowulf Off the Map', ASE 38 (2009), 11-40, at 27 and 21.

77 'The Burgundians have that sea's arm to the west of them and the Swedes to the north, and to the east of them are the Sarmatians, and to the south of them the Sorbs. The Swedes have to the south of them the arm of the sea [called] Osti and to the east of them the Sarmatians, and to the north of them
} 
The accounts are presented as personal experiences rather than objective geography. Ohthere presumably spoke at King Alfred's court; Wulfstan's account follows without any introductory context. The accounts are presented together, but nothing indicates that the two men were at court simultaneously, or even that Wulfstan were there at all. They may have begun as independent records made by court scribes during the seafarers' visits to Wessex, later interpolated into the Old English Orosius to contribute to its account of Northwestern Europe. ${ }^{78}$ As the accounts are partially preserved in the earliest surviving Old English Orosius manuscript, Additional 4796, the interpolation must have occurred at an early date and the accounts are now integral to the geographical section. The two accounts are stylistically and linguistically distinct, reflecting the differing origins of the two travellers. Ohthere explains that he comes from Hålogaland in northern Norway, but Wulfstan's background remains obscure; his name is English and his account bears traces of Anglian dialect, but he speaks as if based in the major trading port of Hedeby in southern Jutland. ${ }^{79}$

Ohthere begins with an account of Hålogaland. He then recalls a voyage along the northern Norwegian coast to the White Sea. After making some ethnographic and linguistic observations about the region, Ohthere describes the characteristics of walruses, and the text notes his gift of walrus ivory to King Alfred. Ohthere then discusses the geography and peoples of the northern lands. He concludes by explaining the sailing route from Hålogaland to the port of Skiringssalr, and then on to Hedeby, giving estimated sailing times and the lands to port and starboard. Wulfstan's section begins at this point and describes the sailing route from Hedeby to Truso, before giving an ethnographic account of Estland. Wulfstan's account ends after the description of the Ests' funeral customs, and the description of the world resumes with Constantinople.

over the waste is Cwenland, and to the northwest of them are the Scridefinnas and to the west Norsemen.

Ohthere said to his lord, King Alfred, that he dwelt northernmost of all the Norsemen. He said that he dwelt in the land northwards along the West Sea.' Old English Orosius, ed. Bately, pp. 13-14.

${ }^{78}$ J. Bately, 'Old English Prose Before and During the Reign of Alfred', ASE 17 (1988), 93-138; J. Bately, 'The Old English Orosius', A Companion to Alfred the Great, ed. N. Discenza and P. Szarmach (Leiden, 2014), pp. 313-43, at 316.

${ }^{79}$ A. Cragie, 'The Nationality of King Alfred's Wulfstan', JEGP 24 (1925), 396-7; C. E. Fell, 'Some Questions of Language', Two Voyagers at the Court of King Alfred: the Ventures of Ohthere and Wulfstan, Together with the Description of Northern Europe from the Old English Orosius, ed. N. Lund (York, 1984), pp. 56-63; M. Townend, Language and History in Viking Age England: Linguistic Relations between Speakers of Old Norse and Old English (Turnhout, 2002), pp. 90-109. 
Ohthere's account, or something very like it, appears to have been the source for the depiction of Scandinavia on the mappa mundi. There is a strong concordance with the geography Ohthere describes, particularly with regards to the map's confusion regarding the location of Iceland. A section of Ohthere's account that has long puzzled critics is the location of the place named Iraland. Ohthere describes sailing from his home to Skiringssalr: 'and on pæt steorbord him bið ærest Iraland, and ponne ða igland pe synd betux Iralande and pissum lande', a position in which it would be difficult to imagine Ireland. ${ }^{80}$ William Craigie was the first to suggest that Iceland was the landmass intended, sparking a storm of critical disagreement. ${ }^{81}$ William Stokoe rejected the identification of Iraland as Iceland on the basis of that the substitution of Iraland for 'Island' would be too great a scribal error. ${ }^{82}$ However, this seems to neglect the fact that we are not reading a text derived from words written by Ohthere, but rather what an Anglo-Saxon scribe recorded. ${ }^{83}$ The scribe was unlikely to have been intimately familiar with sailing the North Sea and could easily have misheard or misapprehended Ohthere's statements. ${ }^{84} \mathrm{~A}$ further scribe then copied the account into the Old English Orosius, which was then copied in turn. Any of those involved in transmitting the text could have made the assumption that Ohthere said the familiar Ireland, rather than Iceland, hence the spelling Iraland. It is difficult to gauge whether Ohthere would have conceived of a land as being to starboard if he could not see it; Iceland may be discounted as being too distant, yet it would have been the first land to that side, and claims for Ireland also rely on Ohthere thinking in terms of sailing routes rather than proximal landmasses. ${ }^{85}$ It seems probable that neither the original scribe, nor the compiler and copyists of the Old English Orosius, were certain what Ohthere meant. Regardless of what Ohthere actually tried to explain, the somewhat corrupt geography of his account does appear

\footnotetext{
80 'And on his starboard will first be Iraland, and then the islands that are between Iraland and this land'. Old English Orosius, ed. Bately, p. 16.

${ }^{81}$ See W. A. Craigie, “"Iraland” in King Alfred’s “Orosius”', MLR 12 (1917), 200-1.

${ }^{82}$ W. C. Stokoe, 'On Ohthere's Steorbord', Speculum 32 (1957), 299-306, at 300. Stokoe presents a useful account of the various identifications of Iraland, before suggesting that Ohthere was thinking in terms of sea routes, with the route to Ireland being the first to starboard.

${ }^{83}$ It is not clear in what language Ohthere gave his account. Perhaps Ohthere spoke English, the court understood Norse, or an intermediary provided translation. All of these scenarios provide ample scope for miscommunication. See: Townend, Language and History in Viking Age England, pp. 90-109.

${ }^{84}$ Ireland is usually Irland in Old Norse (although skotland also occurs), which is close to Iraland, but Ísland, the Old Norse for Iceland, is also similar. Elsewhere the Old English Orosius favours Scotland to translate Hibernia, cf. the assertion 'Igbernia, bæt we Scotland hatað' ('Hibernia, that we call Scotland'): Old English Orosius, ed. Bately, p. 19. The inconsistency is not necessarily problematic, given the separate origins of the accounts. See Old English Orosius, ed. Bately, p. lxxii.

${ }^{85}$ Cf. Stokoe, 'On Ohthere’s Steorbord'.
} 
to have had an influence on the Anglo-Saxon mappa mundi's depiction of Scandinavia and its struggles with situating Iceland.

The mappa mundi displays a landmass named ‘Tylen' (Thule) in the extreme north-west in the location where a modern viewer would expect Iceland. In Classical geography Thule is an island in the extreme north of the world, and this tradition continued in Anglo-Saxon England, for example in Bede’s De temporum ratione §31. Thule is the north-western limit of the world in both the Historiarum adversum Paganos and the Old English Orosius. ${ }^{86}$ The Latin (1.2.79) locates Thule in relation to Britain, after Orkney: 'Deinde insula Thyle, quae per infinitum a ceteris separata, circium uersus medio sita oceani, uix paucis nota habetur'. ${ }^{87}$ The Old English sites Thule in relation to Ireland: 'Ponne be westannorðan Ibernia is pæt ytemeste land pæt man hæt Thila, \& him is feawum mannum cuð for ðære oferfyrre' ${ }^{88}$ Nearer to the date of the map's composition is Ælfric's De temporibus anni, also contained in Tiberius B.v (fols. 24r-28v). Ælfric’s text was written a century after the Norse settlement of Iceland, but based on Bede’s work, and in $\S 19$ he continues to refer to Thule rather than Iceland. Ælfric is a little more accurate than Bede on Iceland's daylength, suggesting contact, but Iceland and Thule are not equated. ${ }^{89}$ It is only later that Thule is understood as Iceland. The Prologue to Landnámabók records:

Í aldarfarsbók peirri, er Beda prestur heilagur gerði, er getið eylands pess er Thile heitir og á bókum er sagt, að liggi sex dægra sigling í norður frá Bretlandi; par sagði hann eigi koma dag á vetur og eigi nótt á sumar, pá er dagur er sem lengstur. Til pess ætla vitrir menn pað haft, að Ísland sé Thile kallað, að pað er víða á landinu, er sól skín um nætur, pá er dagur er sem lengstur, en pað er víða um daga, er sól sér eigi, pá er nótt er sem lengst. En Beda prestur andaðist sjö hundruð prjátigi og fimm árum eftir holdgan dróttins vors, að pví er ritað er, og meir en hundraði ára fyrr en Ísland byggðist af Norðmönnum. En áður Ísland byggðist af Noregi, voru par peir menn, er Norðmenn kalla papa; peir voru menn kristnir, og hyggja menn, að peir hafi verið vestan um haf, pví að fundust eftir peim bækur írskar, bjöllur og baglar og enn fleiri hlutir, peir er pað mátti skilja, að peir voru Vestmenn. Enn er og pess getið á bókum enskum, að í pann tíma var farið milli landanna. ${ }^{90}$

\footnotetext{
${ }^{86}$ Bede, The Reckoning of Time, trans. F. Wallis (Liverpool: Liverpool University Press,, 1999), p. 91.

87 'Then comes the island of Thule, which is separated from the others by an infinite stretch of water and lies to their north-west in the middle of the Ocean. It is known to very few men'. Orosius, Historiarum adversum Paganos, p. 29; Orosius, trans. Fear, p. 45.

88 'Then to the north-west of Hibernia is that outmost land that men call Thule, and it is known to few men because of the excessive distance'. Old English Orosius, ed. Bately, p. 19.

${ }^{89}$ See Ælfric, Alfric’s 'De temporibus anni', ed. and trans. M. Blake, Anglo-Saxon Texts 6 (Cambridge, 2009), pp. 119-20.

90 'In that Book on the reckoning of time, which the Venerable Bede made, the Island called Tili is mentioned, which in books is said to lie six days' sailing north from Britain. There he said day should not come in winter, or night in summer, when day is the longest. To wise men the reason Iceland is
} 
Landnámabók suggests that Bede may have known of Iceland from writings informed by men 'er Norðmenn kalla papa’ (presumably Irish Monks) who inhabited parts of Iceland prior to the Norse settlement. ${ }^{91}$ The draftsman of the mappa mundi has not made this same connection between Thule and Iceland, leading to an apparent duplication.

In addition to representing Thule, the Anglo-Saxon mappa mundi shows a large island off the coast of Scandinavia. It is similar in location and shape to the Norwegian peninsula, and the people listed as inhabiting it, the 'Scridefinnas' may be a name for the Saami. However, it is called 'Island', a name very similar to Ísland, the Norse spelling of Iceland. To the south of 'Island' are two large islands, which may represent Funen and Lolland, and whose location could be described by Ohthere's 'and ponne ða igland pe synd betux Iralande and pissum lande'. ${ }^{92}$ The map's depiction of two islands, both of which could represent Iceland, suggests that the mapmaker was aware of a place called Ísland in the north, populated by Scandinavians, but was unsure of its location, and was also in possession of sources, possibly visual, that precisely located Thule. The result is a neat depiction of Thule, and a peculiar merger of the geography of Norway and Iceland into a new insular space. ${ }^{93}$ The proximity of 'Island' to the Scandinavian coast is logical, based on the centre of Norse population. The location of 'Island' may also have been influenced or confused by Ohthere's account, as its depiction corresponds with his description of the location of Iraland.

called Tili is held to be that, widely about the land the sun shines all night when the day is the longest, and that widely about it the sun is not seen in the day when night is at its longest. But Bede, the Priest, died 735 years after the Incarnation of our Lord, as it is written, and more than one hundred years before Iceland was settled by the Northmen. But before Iceland was settled from Norway there were men there, whom the Northmen called Papar; they were Christian men, and it is thought that they must have come from the west over sea, for there were found after them Irish books, bells, and crosiers, and yet other objects, from which it could be understood that they were Irishmen; and it is mentioned in English books that in those times voyages were made between these countries'. Landnámabók, ed. Hermann Pálsson and P. G. Edwards, University of Manitoba Icelandic Studies 1 (Winnipeg, 1972). ${ }^{91}$ These papa may also be discussed by the ninth-century Irish geographer Dicuil in Liber De Mensura Orbis Terae VII.6-15, in which he describes northern islands, including Thule, based on the accounts of monks. Dicuil, Dicuili Liber De Mensura Orbis Terrae, ed. J. J. Tierney, Scriptores Latini Hiberniae 6 (Dublin, 1967), pp. 72-7.

${ }^{92}$ Which would presumably be Orkney, if Ohthere were referring to Iceland.

${ }^{93}$ On identifying this island as Iceland see: A-D. von den Brincken, Finis Terrae: die Enden der Erde und der Kontinent auf Mittelalterlichen Weltkarten, Schriften der MGH 36 (Hanover: Hahnsche Buchhandlung, 1992), p. 61; L. S. Chekin 'Mappae Mundi and Scandinavia', Scandinavian Stud. 65 (1993), 487-520, at 497. 
Much of the geography of Northwestern Europe on the Anglo-Saxon mappa mundi appears to be an attempt to integrate Scandinavian material with established cartography. The mapmaker struggles to reconcile information about Scandinavia with the need to incorporate places such as Scythia, compressing and merging details in order to fit them into the limited space left by conventional cartography. The map represents the Goths ('Gothia') and Schleswig ('sleswic') to the east of an accurate representation of Jutland, but then connects these regions to Scythia and the River Ypanis. The shape of the Norwegian peninsular is vaguely echoed in that of 'Island', but its name appears farther south on Jutland. Denmark has been labelled 'neronor reori' which is nonsensical, but appears to be based on words for Norse or Norwegian in Old English or Old Norse. ${ }^{94}$ Given the accuracy of the coastline it is somewhat surprising that Denmark should apparently have been labelled as Norway, especially as the map dates from after the reign of Canute. Given Canute's own territorial expansions, the legend may be a reflection on contemporary politics. Alternatively, if (as argued below) the map depends on an exemplar contemporaneous with the murky period in Danish history before the reign of King Gorm, 'neronor reori' would refer to the Norse inhabiting the region. The name suggests a departure from classical sources in favour of more up-to-date local knowledge, but a struggle to display that information cartographically.

Further evidence for the mappa mundi's attempts to integrate Scandinavian knowledge can be seen in the seas of Northern Europe. The Black Sea is depicted as being close to the Baltic and filled with islands. The knowledge of a sea full of islands on the other side of Scandinavia may have led to the perception of the Black Sea as close, particularly as the mapmaker has chosen to draw the Baltic as a very open area, connected to the garsecg in the north. Alternatively, the prominence and proximity of the Baltic may reflect the importance of Scandinavian trade routes into the region. ${ }^{95}$ In the Anglo-Saxon mappa mundi we have cartographic change in progress. New northern information is merged into Late Antique geography, like the interpolation of Ohthere and Wulfstan into the geography of the Old English Orosius.

\footnotetext{
${ }^{94}$ I. Valtonen, The North in the Old English Orosius: a Geographical Narrative in Context (Helsinki, 2008), pp. 231-2. The name Norway is attested from the ninth century: S. Brink, 'Geography, Toponymy and Political Organisation in Early Scandinavia’, Ohthere’s Voyages, pp. 66-73, at 66. This would be the earliest instance in cartography: C. van Duzer and I. Dines, 'The Only Mappamundi in a Bestiary Context: Cambridge, MS Fitzwilliam 254’, Imago Mundi 58 (2006), 7-22, at 10.

${ }^{95}$ On relations between Scandinavia and the Baltic in this period see: Society and Trade in the Baltic During the Viking Age, ed. by S-O. Lindquist and B. Radhe (Visby, 1985).
} 
The mappa mundi's interest in Scandinavia can be attributed to the importance of Anglo-Danish relations from the late-ninth century onwards. The depiction of Jutland is impressively accurate, indicating that good information on the Danish coastline was available to the mapmaker. Such material would undoubtedly have been derived from the accounts of traders, such as Ohthere and Wulfstan, who had travelled in Scandinavia. Although many travellers must have come to Wessex and described their journeys, the accounts of Ohthere and Wulfstan are the only ones which have survived, and they have done so by being interpolated into a text which circulated. Such dissemination would have made them easier for a mapmaker to acquire as a source. It is possible that the mapmaker could also have made use of material found in Old English Orosius, as its geographical section is more up-to-date than the Latin, particularly in regards to Scandinavia. There are other similarities between the mappa mundi and the Old English Orosius. McGurk identifies the tribe named as inhabiting the west of 'Island' on the map, the 'scridefinnas', as probably being cognate with the 'Scirdifrini'/'Scridefinne' mentioned by Adam of Bremen (Gesta Hammaburgensis Ecclesiae Pontificum IV.xxxvi) and the Old English Orosius. ${ }^{96}$ However, the Orosian material on the map must primarily derive from the Latin text as it contains geographical information omitted from the Old English. ${ }^{97} \mathrm{~A}$ direct link between the Old English Orosius and the Anglo-Saxon mappa mundi cannot be proved, but the impetus behind both projects appears to be similar. Both the Old English Orosius and the mappa mundi are concerned with regional centres of power, and have a distinctly rational and accurate view of Northern Europe. The two texts exhibit a distinctly Anglo-Saxon worldview, with the mappa mundi in particular reshaping global geography to reflect local interests. These texts represent a progression in worldview from the continental perspective of a marginal Northwestern Europe articulated by Bede to a new regional confidence driven by shifting continental power structures.

\section{CONCLUSION: CREATING THE NORTHERN WORLD}

\footnotetext{
${ }^{96}$ McGurk, 'The Mappa Mundi', p. 81. Adam of Bremen, Gesta Hammaburgensis Ecclesiae Pontificum, ed. J. M. Lappenberg, MGH ss. rer. Germ. 2 (Hanover, 1826). The Old English Orosius manuscript Tiberius B.i. also spells the name 'Scridefinnas'. Old English Orosius, ed. Bately, p. 13, n. to 1.27$)$.

${ }^{97}$ For example Lake Chalearzum, depicted on the map as 'Lacus Calearsum', is listed in the account of Africa in Historiarum adversum Paganos 1.2.9, but omitted from the Old English Orosius 1.i. Old English Orosius, ed. Bately, p. 9; Orosius, Historiarum Adversum Paganos, p. 11.
} 
Everything about the Anglo-Saxon Map signals its Insular perspective. The legend, with its mixture of languages and letterforms is unmistakably Anglo-Saxon: it derives from Classical learning, Christian history and local knowledge. The information it records interested the Anglo-Saxons and reflected their Insular worldview. But Insular is not isolationist: this map is the product of an island culture keen to emphasize its connections to Rome, its place in the history of empires, and its links to the rest of the world. The Anglo-Saxon mappa mundi is a fundamentally outward looking document, albeit one that declares its vantage point to be in the north-west. The place of Britain on the map asserts its prominence; it occupies the north-western corner of the map, surrounded by sea, rather than squashed against the boundary, as it is on later maps such as the Hereford mappa mundi. Although the Anglo-Saxon mappa mundi follows tradition in locating the British Isles at the edge of the oecumene, its focus on islands serves to emphasise the size of Britain and bring it in from the edge. Michelet has described the mapmaker as giving his country 'a new, regional centrality'. ${ }^{98}$ Britain is labelled 'Brittannia', which, as Catherine Karkov observes, 'immediately suggests its historic British and Roman roots' asserting Britain as belonging to and inheriting the Roman world - Rome itself appears to be fairly nearby. ${ }^{99}$ The level of detail in Northwestern Europe increases the prominence of the region, and describes the space with local knowledge. Several of the names occurring for the first time in the cartographic record are located within and around Britain. The map depicts Winchester and 'Cantia' (Kent) - albeit in the wrong place - and labels part of Scotland as 'camri', which may be a reference to Yr Hen Ogledd. English names spread across the channel with the use of 'suð bryttas' in France, presumably to label the Breton population. Breton refugees fleeing Viking raids strengthened links between Brittany and England in the ninth and tenth centuries; this may contribute to the prominence of the 'suð bryttas' on the mappa mundi. ${ }^{100}$ The density of information provided portrays Britain, and particularly England, as thriving.

Britain's prominence and detail draw the viewer's initial gaze, meaning that its geography influences the interpretation of the entirety of the map. As Karkov observes, the map 'embeds England in shape, name, history and experience in many

\footnotetext{
${ }^{98}$ F. Michelet, Creation, Migration, and Conquest: Imaginary Geography and Sense of Space in Old English Literature (Oxford, 2006), p. 157.

${ }^{99}$ C. E. Karkov, The Art of Anglo-Saxon England (Woodbridge, 2011), p. 289.

${ }^{100}$ The Old English Life of Machutus, ed. D. Yerkes (Toronto, 1984), pp. xxxix-xlii.
} 
times and many places'. ${ }^{101}$ In its entire shape the map mirrors Britain, and particularly England. The numerous islands, jagged coasts, the shape of the continents and their representation as shared island-like spaces echoes Insular space. McGurk observes that the unusual rectangular shape of the map has been utilized to allow the depiction of a greater number of islands and seas rather than enlargement of the landmasses. ${ }^{102}$ This is the response of an island nation for whom the sea was of vital importance - a people who were used to using the sea as a route way, providing a path to economic opportunity. The entirety of the world is not only seen from an English perspective, but also physically related to the English experience of the world. The map's retracing of the world is reminiscent of the refocusing seen in the Old English Orosius, which acknowledges a multiplicity of regional centres between which power shifts, yet presents its narrative from a distinctly north-western perspective. This characteristic viewpoint is particularly clear in the accounts of Ohthere and Wulfstan, which make Wessex a centre by presenting a distant North viewed from that particular vantage point. The prominence of Britain and Scandinavia on the mappa mundi is akin to the importance of those regions in the geographic section of the Old English Orosius: England is in a corner of the world, but one that is thriving and important.

The inclusion of Ohthere and Wulfstan's accounts in the Old English Orosius, and of Scandinavia on the mappa mundi, is reminiscent of Roman imperial interests in the edges of empire. The desire evinced by the Old English Orosius to inherit and supplant Carolingian power, making use of the same techniques that the Carolingians themselves employed to portray translatio imperii from Rome to Aachen, is also in evidence on the Anglo-Saxon mappa mundi. The map offers a synchronic view of empire: numerous cities appear on the map, representing the progression of power from East to West. By making England so full of cities the map suggests the AngloSaxon kingdom as part of this pattern of translatio imperii. The idea that a map of the world could convey the shifting nature of temporal power finds a Carolingian parallel in Theodulf of Orleans's 'Carmen 47', which describes a table map. ${ }^{103}$ Theodulf blurs the fixed seat of the earth with the seats of worldly power to ponder impermanence:

Per sedes etiam mundi signantur honores,

\footnotetext{
${ }^{101}$ Karkov, Art of Anglo-Saxon England, p. 291.

102 McGurk, 'The Mappa Mundi', p. 80.

103 Theodulf's Carmina 46 and 47 are discussed by Kupfer: 'Medieval World Maps', pp. 265-7. On the identification of the subject as a map see M. A. Vidier, 'La mappemonde de Théodulfe et la mappemonde de Ripoll (IX ${ }^{\mathrm{e}}-\mathrm{XI}^{\mathrm{e}}$ siècle)’, Bulletin de géographie historique et descriptive (1911), 285313.
} 
Perpetuo quod eos nemo habiturus adit.

Alter in alterius gaudet residere cathedra,

Hic sedet, hic sedir, hic it, et ille redit. (27-30) ${ }^{104}$

Theodulf's playful polyptoton in 1. 30 highlights the idea that worldly power fluctuates. Theodulf's map, whether real or imagined, conveys the idea of translatio imperii. In the Carolingian world a mappa mundi was both a statement of imperial power, and, through its synchronic representation of the world, an acknowledgement that such power shifts. How such shifts would be read would depend on the context in which the map were viewed; for Bishop Theodulf a map communicates the temporally limited nature of the world, in a more secular context such instability would suggest opportunity. It is tempting to view the Anglo-Saxon mappa mundi as depending on a larger exemplar that was the product of Anglo-Saxon England in the tenth century, when such Carolingian emulation came into vogue. Imperial ambitions would be amplified in this larger-scale version because of the association of world maps with imperial power. The copying of this map in the early eleventh century echoes that of the Old English Orosius in the same period: three of the four surviving manuscripts and fragments are early-eleventh-century. ${ }^{105}$ Support for a tenth-century exemplar for the map is also to be found in the map's Frankish connections: the mappa mundi must, like the Old English Orosius, depend on Roman material transmitted through Carolingian copyists. ${ }^{106}$

The map as we have it is assertively English, as the representation of the British Isles and its echoes in the geography of the oecumene make clear, but the map's features reveal precursors in Roman mapping, with Francia as the route of transmission. Emily Albu has convincingly argued that Carolingian interests in Roman cartography must account for the preservation of the Roman layout of the thirteenth-century Peutinger map. ${ }^{107}$ Francia must also be responsible for transmitting and preserving aspects of the layout of the Anglo-Saxon mappa mundi: the adaptation of Roman material, the interest in empires and the integration of scriptural material all

\footnotetext{
104 'The honours of the world are signified by the seat also, because none will have them eternally. One rejoices to sit in the seat of another: this one sits, this one sat; this one goes, and that one returns'.

Poetae Latini Aevi Carolini, ed. E. Dümmler, MGH Poetarum Latinorum Medii Aevi 1 (Berlin, 1881), p. 548. Translation from: N. A. Alexandrenko, 'The Poetry of Theodulf of Orleans: A Translation and Critical Study', (Tulane).

${ }^{105}$ Cotton Tiberius B.i, Bodleian Eng. Hist. e. 49 (30481) and Vatican City, Reg. lat. 497.

${ }^{106}$ Lapidge makes the point that Carolingian knowledge of classical learning runs ahead of that of Anglo-Saxon England, making Francia the logical route of transmission for Roman mapping. Lapidge, The Anglo-Saxon Library, pp. 129-31.

${ }^{107}$ Albu, 'Imperial Geography'.
} 
speak to this. Aspects of both Tiberius B.v's maps, particularly the icons of cities, find clear parallels in Carolingian copies of Roman materials. The cities on the Anglo-Saxon mappa mundi and the zonal map are shown in semi-perspective as walled and turreted polygonal enclosures. ${ }^{108}$ This polygonal city design originated in Roman art and is replicated in Carolingian copies of Roman images, such as the depictions of cityscapes in the Agrimensores. ${ }^{109}$ Similar polygonal cityscapes occur in the Utrecht Psalter (Utrecht, Universiteitsbibliotheek, MS Bibl. Rhenotraiectinae I Nr 32), for example Ps. 9 on f. 5r. This highly influential masterpiece of Carolingian art was in Anglo-Saxon England by the end of the tenth century, and its cities are replicated in the Harley Psalter (British Library, Harley 603, Canterbury, s.x/xi). ${ }^{110}$ The influence of Carolingian architectural representation in semi-perspective can also be seen in the donation image of King Athelstan in Cambridge, Corpus Christi College 183, f. $1 \mathrm{v}$. The style of the church, with layers of tiles of various designs, closely echoes that of the easternmost city on the Macrobian zonal map. As Carolingian copies were the means by which the semi-perspectival polygonal Roman cityscape was preserved in medieval Europe, the cities of the Tiberius B.v maps suggest dependence on the Carolingian transmission of Roman material.

If the ancestry of the Anglo-Saxon mappa mundi lies in Francia, when might the model for the map have arrived in Anglo-Saxon England, and its cartography been updated to acquire a distinctly Insular perspective? It is tempting, albeit very speculative, to assign the presence in England of a large wall-map of Carolingian origins to the reign of Athelstan. Athelstan is known for his ownership and

\footnotetext{
${ }^{108}$ Like the Pillars of Hercules, the design of the cities connects the two images of the world.

${ }^{109}$ For example, Vatican, Biblioteca Apostolica Vaticana, Pal. lat. 1564 (Aachen court, c. 830-900): W. Kaiser, 'Spätantike Rechtstexte in agrimensorischen Sammlungen', Zeitschrift der Savigny-Stiftung für Rechtsgeschichte:Romanistische Abteilung 130 (2013), 273-347, at 282. On cityscape illustration in the Roman, Late Antique and Carolingian eras see: J. N. Carder, Art Historical Problems of a Roman Land Surveying Manuscript: the Codex Arcerianus A, Wolfenbüttel (New York, 1978), pp. 189-95. See also: J. Deckers, 'Tradition und Adaptation. Bemerkungen zur Darstellung der christlichen Stadt', Mitteilungen des deutschen archaeologischen Instituts, Römische Abteilung 95 (1988), 303-382, at 310-11; O. A. W. Dilke, 'Illustrations from Roman Surveyors' Manuals', Imago Mundi 21 (1967), 929; F. Mütherich, Studies in Carolingian Manuscript Illumination (London, 2004), pp. 118-46. A similar design is seen in the sixth-century Vienna Genesis (Vienna, Österreichische Nationalbibliothek, cod. theol. gr. 31), in images such as Rebecca at the well. Carder, Art Historical Problems, p. 193. This Byzantine manuscript was produced in Syria but is linked to Roman styles of urban representation. A similar hexagonal pattern appears in early-modern copies of the Roman Notitia Dignitatum: Deckers, 'Tradition und Adaptation', pp. 311-12. I am grateful to Dr Tina Bawden (Freie Universität Berlin) for drawing my attention to the similarities.

${ }^{110}$ F. Wormald, English Drawings of the Tenth and Eleventh Centuries (London, 1952), p. 21. Gneuss and Lapidge, Anglo-Saxon Manuscripts, pp. 680-1. Gneuss and Lapidge, Anglo-Saxon Manuscripts, pp. 344-5.
} 
dissemination of continental manuscripts, building on Alfred's earlier acquisitions. ${ }^{111}$ Sarah Foot highlights the way in which Athelstan's imperial ambitions would have been encoded in to the visual culture of his court, particularly through the gifts brought by Hugh, duke of the Franks, many of which had Byzantine associations, and the symbolism of the crown. ${ }^{112}$ Athelstan clearly had an interest in the East; Foot notes the use of the Greek imperial title basileus in his charters. ${ }^{113}$ The Anglo-Saxon mappa mundi shows a similar interest, representing a number of cities belonging to the Byzantine Empire, connecting Anglo-Saxon England to the East. As Michael Wood argues, the receipt of Hugh's generous gifts, many of them with imperial associations 'may have implied a translatio imperii ... some of Charlemagne's own divine favour and virtus now passed to Athelstan, who was certainly entitled to think that there was no continental king to rival him.' 114 Some of Athelstan's contemporaries clearly saw him as the successor to Charlemagne: a certain Peter, the poet of Carta dirige gressus, adapted a poem dedicated to the emperor to praise Athelstan's achievements. ${ }^{115}$ To Athelstan, an ambitious collector of impressive manuscripts and objects, a large wall-map, echoing Charlemagne's display of cartography as a statement of power, would seem just the thing.

The distinctly Insular aspects of the map’s perspective, such as reference to the Bretons, Scandinavian material, and the prominence of London, speak to a tenthcentury origin. The use of Britannia to label Britain on the map echoes Athelstan's repeated use of 'Rex Totius Britanniae' on his coinage and claims that he exercised rule over all of Britain. ${ }^{116}$ Barber's suggestion that the exemplar of the map, like that of some of the other contents of Tiberius B.v, was at Glastonbury, would fit well with these possible royal connections. ${ }^{117}$ As Gautier Dalché highlights, mappae mundi

\footnotetext{
${ }^{111}$ S. Keynes, ‘King Athelstan’s Books’, Learning and Literature in Anglo-Saxon England: Studies Presented to Peter Clemoes on the Occasion of His Sixty-Fifth Birthday, ed. M. Lapidge and H. Gneuss (Cambridge, 1985), pp. 143-202; D. Pratt, 'Kings and Books in Anglo-Saxon England', ASE 43 (2014), 297-377.

112 S. Foot, Ethelstan: The First King of England (New Haven, CT, 2011), pp. 215, 192-8 and 216-23.

113 Ibid. pp. 197 and 213.

${ }^{114}$ M. Wood, 'The Making of Athelstan's Empire: An English Charlemagne?', Ideal and Reality in Frankish and Anglo-Saxon Society, ed. P. Wormald, D. Bullough and R. Collings (Oxford, 1983), pp. 250-72, at 267.

${ }^{115}$ M. Lapidge, 'Some Latin Poems as Evidence for the Reign of Athelstan', ASE 9 (1980), 83-93. See also Robert Gallagher, 'Latin Acrostic Poetry in Anglo-Saxon England: Reassessing the Contribution of John the Old Saxon', MAE 86 (2017), 249-74, at 268.

${ }^{116}$ C. E. Blunt, 'The Coinage of Athelstan, King of England, 924-939: A Survey', BNJ 42 (1974), 35106; G. Molyneaux, The Formation of the English Kingdom in the Tenth Century (Oxford, 2015), pp. 209-12.

${ }^{117}$ Barber, 'Medieval Maps of the World', p. 4; Barber, 'Updating the Roman World', p. 25.
} 
were popular in a school context in the Carolingian world. ${ }^{118}$ Under Dunstan tenthcentury Glastonbury became a great school, with royal patronage and access to a wide variety of learning; it is easy to see how a detailed mappa mundi might be of interest in such a context. ${ }^{119}$ Saturn's description of a world made of islands in Solomon and Saturn I, a poem that has been connected to Dunstan, might even be seen as reflecting the image presented by the map:

Saturnus cwæð:

Hwæt! Ic iglanda eallra hæbbe

boca onbyrged purh gebregdstafas, larcræftas onlocen Libia and Greca, swylce eac istoriam Indea rices. (ll. 1-4) $)^{120}$

All these places are visible on the mappa mundi, emphasizing the sweeping scale of Saturn's claims. But while a compelling case can be made that a mappa mundi would be of interest to Athelstan and Dunstan, and that the Anglo-Saxon mappa mundi reflects their milieux, there is no evidence to ascribe its origins to either of their circles. A stronger case can be made for placing the Old English Orosius in this context. The text was copied in Athelstan's England by a Winchester scribe who also worked on the Parker Chronicle, and its initials are echoed in the Junius Psalter. ${ }^{121}$ It reflects Athelstan's interests through the way it reshapes the Latin source material.

The same reconfiguration according to the interests and ambitions of later Anglo-Saxon England seen in the Old English Orosius is applied to the oecumene on the Anglo-Saxon mappa mundi. By drawing the viewer's attention to Britain through its scale and prominence, and representing England as urbanized, the map places the Anglo-Saxon dominion as part of a pattern of translatio imperii that connects to the Roman world, rendering explicit that which Leneghan sees as embedded in the translation style of the Old English Orosius. The map is arguably more assertive in its representation of English power than the prose text. Although the Old English Orosius depends on Frankish knowledge it has little to say on Francia; the same is

\footnotetext{
118 Gautier Dalché, La 'Descriptio Mappae Mundi', pp. 95-100.

119 See M. Atherton, The Making of England (London, 2017), pp. 192-202.

120 'Saturn said: "Listen, I have tasted of the books of all the islands, through woven letters unlocked the erudition of the Libyans and Greeks, likewise also the history of the Indian kingdom”'. The Old English Dialogues of Solomon and Saturn, ed. and trans. D. Anlezark, Anglo-Saxon Texts 7 (Cambridge, 2009), pp. 60 and 61. On connections to Dunstan see Ibid. pp. 49-57.

${ }^{121}$ Ker, Catalogue, pp. 164-6, n. 133 and 408-9, n. 335; D. Dumville, 'The Anglo-Saxon Chronicle and the Origins of English Square Minuscule Script', Wessex and England from Alfred to Edgar: Six Essays on Political, Cultural and Ecclesiastical Revival, ed. by D. Dumville (Woodbridge: Brewer, 1992), pp. 55-99, at 67-8; F. Wormald, 'Decorated Initials in English MSS. from A.D. 900 to 1100', Archaeologia 91 (1945), 107-35, at 118.
} 
true of the map, which urbanizes England without doing the same to northern Europe. But whereas the shift to an assertively English perspective in the Old English Orosius is brief, occurring only in Ohthere's account, this viewpoint is sustained on the map. Rather than the uncomfortable jolt into the northern perspective of the sailing accounts in the Old English Orosius, the map presents a smoother integration of northern and Mediterranean knowledge, offering a sustained Insular image of the world.

As Michelet notes when comparing the interpolation of the accounts of Ohthere and Wulfstan into the Old English Orosius with Charlemagne's table maps, 'to know is also somehow to dominate'. ${ }^{122}$ The production of a detailed view of the world on the mappa mundi declares Anglo-Saxon England's importance and influence. Tiberius B.v preserves an eleventh-century copy of a map that was probably the product of an assertive tenth-century England. The Anglo-Saxon mappa mundi is a visual expression of later Anglo-Saxon England's way of imagining the oecumene and their place within it. The map depicts a world of islands and multiple regional centres in which England appears as a continuation of the Roman Empire. The whole oecumene has been made to look like Britain, asserting the integration of Britain into the known, civilized world: it is a centre rather than a margin. The AngloSaxon mappa mundi presents an image of the world viewed with northern, Insular eyes.

HELEN APPLETON

BALLIOL COLLEGE, OXFORD helen.appleton@ell.ox.ac.uk

${ }^{122}$ Michelet, Creation, Migration, and Conquest, p. 27. 


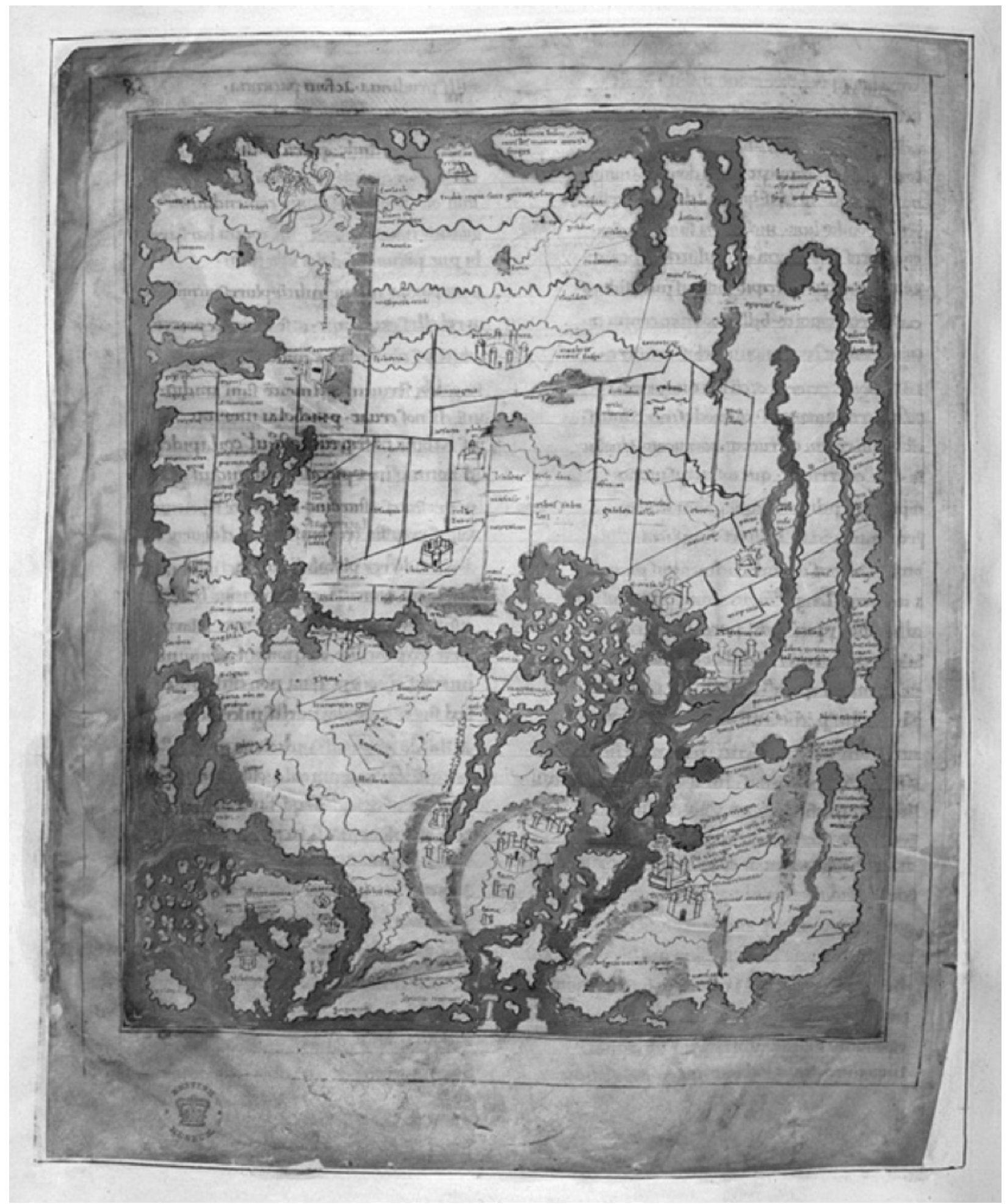

Fig. 1: London, British Library, Cotton Tiberius B.v, f. 56v. The Anglo-Saxon mappa mundi. East is at the top. 


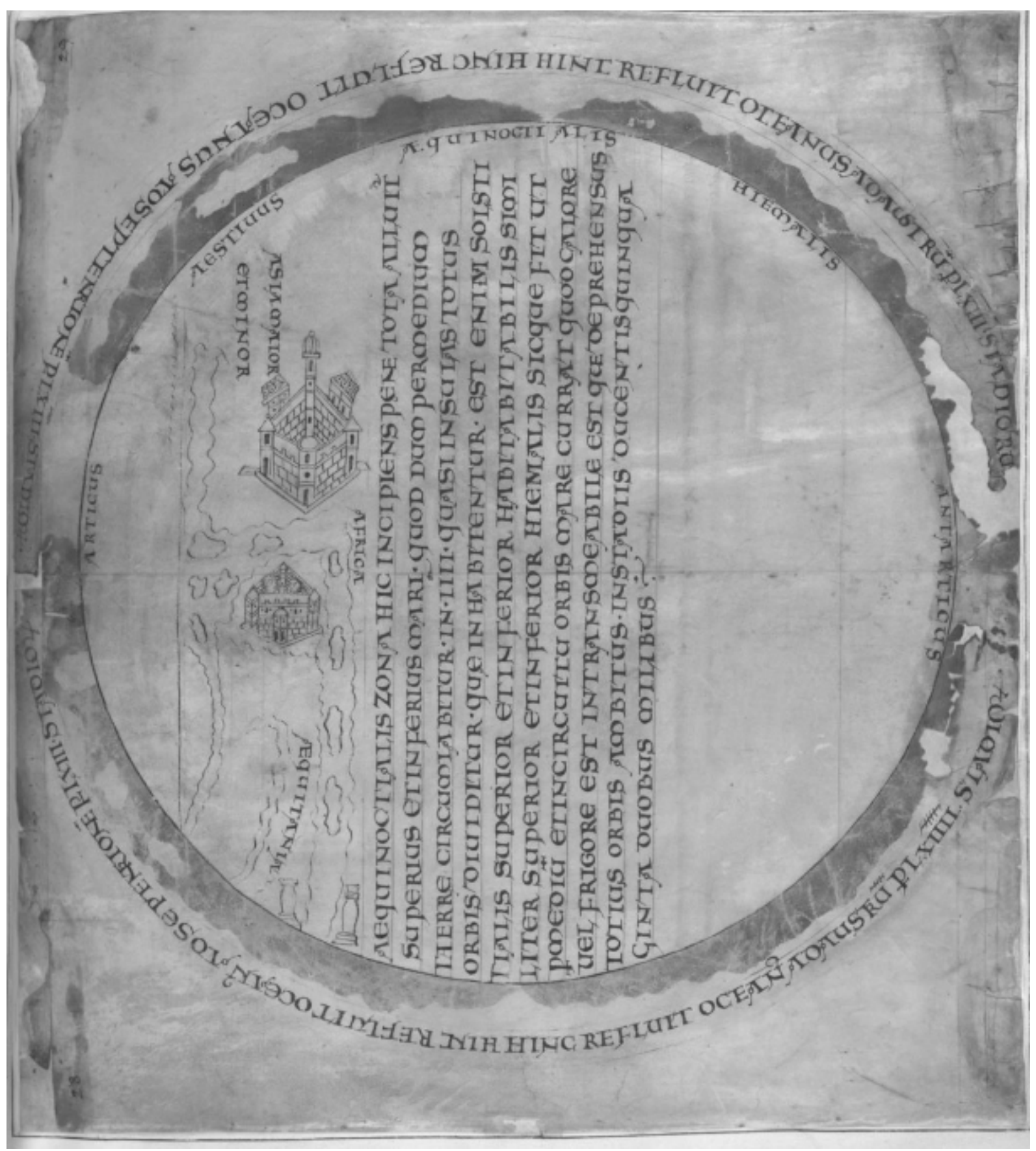

Fig. 2: London, British Library, Cotton Tiberius B.v, f. 29r. Macrobian zonal map. East is at the top. 